\section{Jurnal Hukum Volkgeist \\ Volume 5 Issue 2, 2021 \\ P-ISSN : 2528-360X, E-ISSN : 2621-6159}

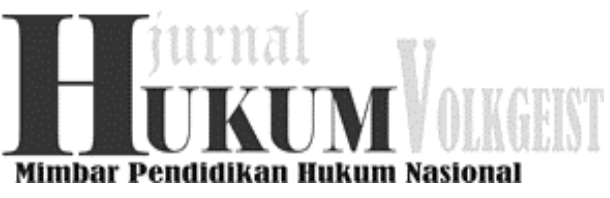

Mimbar Pendidikan Hukum Nasional

\title{
An Analysis of The Offense of Unpleasant Action in Article 335 Paragraph (1) of The Indonesian Criminal Code
}

\author{
Xavier Nugraha $^{1 *}$, Kusuma Wardani Raharjo ${ }^{1}$, Ahmad Ardhiansyah ${ }^{1}$, Alip \\ Pamungkas Raharjo ${ }^{1}$
}

\begin{abstract}
The Constitutional Court as the guardian of the constitution and the guardian of human rights has the duty to ensure that the Law does not contradict the constitution and does not violate human rights. One of the manifestations of this can be seen in the Constitutional Court Decision Number 1 / PUU-X/2013, where the Constitutional Court removed the element "Some other deeds or unpleasant treatment/act" in Article 335 paragraph (1) of the Criminal Code. With the removal of the core elements of Article 335 paragraph (1) of the Criminal Code, raises questions related to the existence of the offense whether it still exists or not. Based on this, this study will examine 1) Application of Article 335 of the Criminal Code Before the Decision of the Constitutional Court Number 1 / PUU-X / 2013 and 2.) Application of Article 335 of the Criminal Code After the Decision of the Constitutional Court Number 1 / PUU-X / 2013. This research is a normative legal research with a statute approach, conceptual approach, and case approach. Based on this research, it was found that after the Constitutional Court Decision Number 1 / PUU-X / 2013 that offenses of unpleasant acts had been reconstructed into forced offenses
\end{abstract}

Keyword: Article 335 paragraph (1) of the Criminal Code, , Decision of the Constitutional Court Number 1 / PUU-X/2013, Unpleasant Acts

1. Introduction

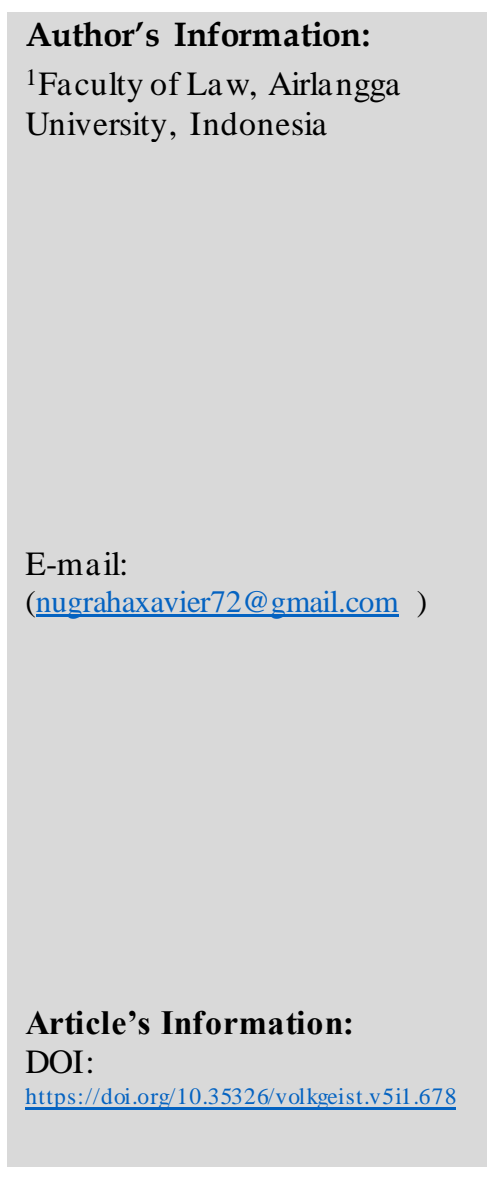

"Ex vero nonnisi verum", a legal adage which means a true concept, can produce the correct conclusions (M.Hadjon \& Djamiati, 2008). One concept of offense in the Criminal Code (KUHP) which is being debated by the general public is the existence of an offense of unpleasant act that has been stated earlier in Article 335 paragraph (1) of the Criminal Code, which in the concept of the article reads:

"(1) Threatened with a maximum imprisonment of one year or a maximum fine of four thousand five hundred rupiah: Number 1 . An yone who unlawfully forces others to do, not do or allow something, by using violence, something else or unpleasant treatment, or by using the threat of violence, some unpleasant treatment, both towards the person himself or others; 2 . Who is forcing others to do, not to do or allow something with the threat of defamation "

The existence of the offense is deemed to be an article that can apply to anyone who performed an unpleasant treatment on others, because there are no definite indicators or benchmarks in its enforcement. This opinion is also in line with the 
statement of Hamdan Zoelva as the former Chair of the Constitutional Court of the Republic of Ind onesia for the period of 2013 to 2015 stating that unpleasant act offense, cannot be measured objectively, even if it can be measured then the measure is very subjective and based only on the evaluation of victims, investigators and prosecutors only.

This proves that the existence of the offese in Article 335 paragraph (1) point 1 of the Criminal Code does not fully reflect the principle of legality whose position in criminal law becomes the most important or fundamental principle. That is because the provisions of Article 335 paragraph (1) point 1 of the Criminal Code injure an important aspect in the principle of legality which is the existence of criminal provisions must be formulated in the form of written regulations (lex scripta), clearly formulated (lex certa) and must be interpreted strictly, including therein prohibition on interpretation of analogies (lex stricta) (Hiariej, 2015)

It is not clear and multiple interpretations that the offense of this unpleasant act can lead to a form of abuse of power and authority or power and abuse de droit. If it is associated with proof of offense, it includes the following (Soesilo, 1994):

a. That there are people who against their right are forced to do something, not do something or let something happens;

b. Coercion is carried out by using violence, a form of act or an unpleasant act, or the threat of violence, or the threat of an unpleasant act, either against that person, or against another person

Only by matching one of the elements such as the element of threat of violence involving an unpleasant act, the offense can be charged to ensnare others in order to get criminal sanctions. The lack of a clear written concept of the meaning of this unpleasant act allows abuse of authority by law enforcement officials such as investigators, and public prosecutors. The form of authority abuse that might appear is in the form of the following (Arinanto \& Triyanti, 2009):

1. Misuse of authority to take actions that are contrary to the public interest or to benefit personal, or group interests;

2. Misuse of authority in the sense that the official's actions are properly intended in the public interest, but deviates from the purpose of what authority is given by law or other regulations;

3. Abuse of authority in the sense of abusing procedures that should be used to achieve certain goals, but has used other procedures to do so.

Thus, the existence of the offense does not manifest the purpose of the law itself, according to Gustav Radbruch, there are three basic values which are the objectives of the law, namely the principle of justice (gerectigheit), expediency (zwechmatigheid), and legal certainty (rechtmatigheid). Even this offense can potentially harm either party if it is still applied without definite benchmarks (Faisal, 2010).

One of the disadvantages of unpleasant act offense was felt clearly by Oei Alimin Sukamto Wijaya who submitted a judicial review to the Constitutional Court with Case Application Number 1 / PUU-X / 2013. As long as the phrase "Some/ A form of other deeds or unpleasant treatment" contained in Article 335 Paragraph (1) of the Criminal Code according to wisdom from Oei Alimin Sukamto Wijaya which has been determined as a suspect by Surabaya Police with Number S-Pgl / 3567 / X / 2012 / RESKRIM, the existence of the phrase gives rise to a form of differentiation between 
position and treatment (unequal treatment), injustice (injustice), legal uncertainty. The Constitutional Court which holds the title of The Guardian of Constitusion, in its legal considerations considers that:

[3.15] According to the Court as a formulation of offense, qualification s, "Some other deeds or unpleasant treatment/act or offense" cannot be measured objectively. Even if it can be measured, the measurement is very subjective and is only based on the assessment of victims, investigators and public prosecutors only. In addition, the unpleasant thing is generally the impact of all criminal acts. Every crime is clearly unpleasant and there is no unpleasant impact of the crime. Thus, this is not something that can distinguish explicitly (distinctive) from other criminal acts;

[3.16] As a result of the existence of such an offense formula, it can also be an opportunity for investigators and public prosecutors to arbitrate others based on a report. Although it must be admitted that in the end such matters must be proven in court, but if the report is proven, it becomes a norm and there is no arbitrariness. Conversely, if it is not proven, then the reported party has clearly suffered losses due to having to deal with investigators and public prosecutors and moreover if the person concerned is detained [vide article 21 paragraph (4) letter b of the Criminal Procedure Code].

Thus, it means that someone has lost independence as their human right, even though the criminal law and criminal procedure law are precisely to protect human rights from the arbitrariness of law enforcers. In addition, the person concerned is morally and socially disadvantaged as he or she has been stigmatized as a despicable person as a result of the report; The legal considerations lead to change along the phrase "Some other deeds and unpleasant treatment" in Article 335 paragraph (1) point 1 of the Criminal Code declared contrary to the 1945 Constitution of the Republic of Indonesia, has no binding legal force anymore. This, of course, then raises questions related to the existence of the offense of unpleasant acts regulated in Article 335 paragraph (1) of the Criminal Code, bearing in mind that one of the core elements of the article is the element "Something other acts/deeds or unpleasant treatment"

If the element is removed, will the deletion also apply to the offense regulated in Article 335 paragraph (1) of the Criminal Code, as the offense in that article is often referred to as "unpleasant acts" offense. Of course, it is very strange, when the offense of "unpleasant act" can still be referred to as "unpleasant act" when the element of "Some other acts and unpleasant treatment" is removed.

It turns out that in practice, the offense regulated in Article 335 paragraph (1) of the Criminal Code is still valid, for example in Decision Number 1554 K / PID / 2013 and 607 / Pid.B / 2015 / PN Kag. This raises the question, related to what is the form of offense regulated in Article 335 paragraph (1) of the Criminal Code after the Constitutional Court Decision Number 1 / PUU-X / 2013? In addition, is it still appropriate when the offense regulated in Article 335 paragraph (1) of the Criminal Code is referred to as an offense of "unpleasant acts"? With these basis, the formulation of the problem in this study include

1. Application of Article 335 of the Criminal Code Before the Decision of the Constitutional Court Number 1 / PUU-X / 2013 ?

2. Application of Article 335 of the Criminal Code After the Decision of the Constitutional Court Number 1 / PUU-X / 2013? 


\section{Method}

This research is a legal study/research. Alegal research is research whose main characteristic is examining the application of a case accompanied by legal arguments / considerations made by law enforcers, as well as the interpretation behind the enforcement of the law (Nugraha, Izzaty, \& Putri, 2019). This legal research is normative legal research, where normative legal research is research on legal principles, a research on legal systematics, research on the synchronization level of law, previous legal history studies (Muhdlor, 2012). This normative research is carried out by reviewing and analyzing the laws and regulations or other legal materials related to unpleasant act offenses regulated in Article 335 paragraph (1) of the Criminal Code.

The approach used in this study is the statute approach, conceptual approach, and case approach. Statute approach is carried out by examining all laws and other regulations relating to legal issues that inquestion, so the ratio legis is found, ontological basis and philosophical basis of regulations relating to the offense of unpleasant acts regulated in Article 335 paragraph (1) of the Criminal Code (Ibrahim, 2017)

Conceptual approach is an approach that moves from the views and doctrines that develop in the science of law to analyze the existence of legal problems (Barus, 2017). In this research, the conceptual approach used is legal concepts related to the offense of unpleasant acts.

Case approach is an approach that uses judges' decisions as a source of legal material. These decisions are judges' decisions that have permanent legal force. The matter discussed in the court decision which has legal force is in the ratio decidendi, namely the legal reasons used by the judge in determining the decision (judgment), which in this study is contained in Decision of the Constitutional Court Number $1 /$ PUU-X / 2013 (Budiyanto, C., Prananto, Tan, F, 2019).

\section{Result and Discussion}

\subsection{Analysis of the Application of Article 335 of the Criminal Code Before the Constitutional Court Decision Number 1 / PUU-X / 2013}

The emerging controversy regarding the enactment of unpleasant act offenses is rooted in the elements contained in Article 335 paragraph (1) point 1 of the Criminal Code which is generally formulated in elements, among others, are the following (Wirjono Prodjodikoro, 2003):

\section{a. For who;}

The purpose of whoever here refers to legal subjects who match the unpleasant act offenset. Because what is meant by legal subjects is a person as an individual with certain intention, in the formulations of criminal acts in the Criminal Code reveal the ability of thinking as a condition for the subject of the crime, also seen in the form of punishment / criminal contained in the articles of the Criminal Code, are imprisonment, confinement, and fines.

\section{b. Against the Law;}

An action can be said to be an unpleasant act as it fulfill the element that the act was carried out against the law. Based on the opinion of Satochid Kartanegara interpreting against the law (Wederrechtelijk) in criminal law is divided into formal Wederrechtelijk formil, that is if something is prohibited and threatened with 
punishment by the law and Wederrechtelijk Material, that is, something may be deemed to be a Wederrechtelijk, but is nor enforced to be likely to be punished by the law .

c. Forcing others to do, not do or allow something;

The element of forcing people is to do an action using a coercive tool and without the coercive tool the coerced person at that time will not want to do what the coercive wants. By using violence, something other actions or unpleasant treatment, or by using the threat of violence, something of other actions or unpleasant treatment, both to the person himself and others. In this offense there are two kinds of ways to force, namely:

1) With violence or other real actions or unpleasant act;

2) With threat of violence or some other real action, or unpleasant act.

The existence of the elaboration of theoffense elements is to prove that the extent of the scope of a person who may be exposed to a crime in accordance with Article 335 paragraph (1) point 1 of the Criminal Code as they are considered to have committed an unpleasant act. Until 1987 the Supreme Court also in its decision no.675 K / Pid / 1985 of August 4, 1987 which was intended to improve the acquittal (vrijspraak) of the Ende District Court Number: 15 / Pid.B / 1984 of March 26, 1985, tried to provide an interpretation regarding the explanation of unpleasant criminal act namely: "with some deed, unlawfully forcing people to let something happen".

The extent of the elements has also resulted in law enforcement officers, especially the public prosecutor who has misunderstood the criminal acts contained in Article 335 paragraph (1) point 1 of the Criminal Code therefore on May 23, 1995, the Attorney General's Office of the Republic of Indonesia issued letter number B-337 / E / $5 / 1995$ with regard to the application of article 335 of the Criminal Code. The contents of the letter issued by the Attorney General's Office of the Republic of Ind onesia further explained the elements contained in Article 335 paragraph (1) point 1 of the Criminal Code, among others, such as:

a) Against Human rights;

b) Forcing others to do, not do or allow something to happen;

c) Coercion is carried out by using violence, something else or an acts that are not pleasant or with threat of violence, the threat of other acts or the threat of unpleasant acts

d) Coercion or threat is directed against both the person himself and others.

The elucidation of the article elements was made clear because of the very worrying tendency towards implementation related to the words of Article 335 paragraph (1) point 1 of the Criminal Code by the public prosecutor who used the article to encompass and coerce all acts into unpleasant acts which lead to the act of imprisoning someone in a manner that is a crime which is exaggerated. This is due to the existence of the element of "unpleasant behavior (onaangename) which has a vast multiple interpretations. Then, the Attorney General's Office of the Republic of Indonesia, as the government agency that exercises state power in the field of prosecution and other law authorities, issues letter number B-337 / E / 5/1995 with regard to the application of article 335 of the Criminal Code as a follow up to a Meeting between Attorney General with the House of Representatives Commission III at the end of 1994. Although there have been efforts to clarify the enactment of Article 335 paragraph (1) point 1 of the Criminal Code, in its development, it will still be implemented in multiple interpretations due to the phrase "unpleasant acts". 
The existence of a multi-interpretation offense is contradictory or incompatible with one of the principles of criminal law, ultimum remedium. The real meaning of Ultimum remedium is the last tool (Mertokusumo, 2009). This has the meaning that the criminal prosecution should be used as the last tool in dealing with one's actions, it is not permissible if all actions are included in the criminal domain, especially in the formulation of offenses that are made to have multiple interpretations as well as the offenses for unpleasant acts contained in Article 335 paragraph (1) item 1 of the Criminal Code, which will have an effect on overcriminalization. Based on Barda Nawawi Arief interpretation of overcriminalization as a lot or an abundance of criminalized acts (Arief, 2000). The indicator of a rule said to be overcriminalized are the following :

1. criminal offenses that cannot be maintained anymore because they do not meet the criteria to be categorized as prohibited acts;

2. excessive criminal legislation;

3. he threat of disproportionate criminal sanctions; and

4. excessive law enforcement for minor violations.

Cum adsunt testimonia rerum quid opus est verbis, when evidence and facts already exist,the words has no use. It can be seen that the phrase "unpleasant act" clearly causes Article 335 paragraph (1) of the Criminal Code to be overcriminalization, bearing in mind that there is no clear definition of unpleasant behavior, or any indicators of an action are said to be included in the unpleasant category, how to prove an action is unpleasant and so on.

\subsection{Analysis of the Implementation of Article 335 of the Criminal Code After the Constitutional Court Decision Number 1 / PUU-X / 2013}

The Constitutional Court is a high state institution that serves as the guardian of the constitution and the guardian of the human rights (Sudirman, 2016). This has juridical consequences, with the duty of the Constitutional Court to ensure that the Act does not conflict with the constitution and ensure that the Act does not violate human rights. One form of the implementation of the duties of the Constitutional Court can be seen through Decision Number 1 / PUU-X / 2013. In the Constitutional Court Decision Number 1 / PUU-X / 2013, the Constitutional Court conducted a reconstruction of Article 335 paragraph (1) of the Criminal Code.

Amendment to Article 335 paragraph (1), especially in point 1 of the Criminal Code now reads, "Anyone who unlawfully forces others to do, not do or allow something, by using violence, or by using threats of violence, both against the person himself or herself or other people". If compared to the ones before the Constitutional Court Decision Number 1 / PUU-X / 2013, the omitted phrase is the phrase "some other deeds or an unpleasant act".

If we compare with the original arrangement in the Netherlands Wetbook van Straafrecht, which is the source of the Netherlands Wetbook van Straafrecht for Hindi (Under Article 131 Indische Staatsregeling, then the Netherlands Wetbook van Straafrecht is applied to Indigenous descendants as the Netherlands Wetbook van Straafrecht for Hindi, which is then based on Article 131 Indische Staatsregeling, now referred to as Wetboek van Strafrecht based on Article 6 of Law Number 1 of 1946 concerning Criminal Law Regulations (Prianter Jaya Hairi, 2016), we can find the 
original offense from Article 335 of the Criminal Code in Article 284 of the Netherlands Wetbook van Straafrecht.

In Article 284 of the Netherlands Wetbook van Straafrecht, it is stated that:

1. Met gevangenisstraf van ten hoogste twee jaren of geldboete van de vierde categorie wordt gestraft:

a. $\quad$ 'hij die een ander door geweld of enige andere feitelijkheid of door bedreiging met geweld of enige andere feitelijkheid, gericht hetzij tegen die ander hetzij tegen derden, wederrechtelijk dwingt iets te doen, niet te doen of te dulden;

b. ${ }^{\circ}$ hij die een ander door bedreiging met smaad of smaadschrift dwingt iets te doen, niet te doen of te dulden.

2. In het geval onder 2 omschreven wordt het misdrijf niet vervolgd dan op klacht van hem tegen wie het gepleegd is

Which Translated into :

1. The following will be punishable by imprisonment of not more than two years or a fourth category fine:

a. ${ }^{\circ}$ Anyone who illegally forces others to do, not do or tolerate something by force or other facts or by threatening with violence or other facts, is directed either at that person or against a third party;

b. ${ }^{\circ}$ Anyone who is forcing others to do something, not doing it or tolerating it by threatening or threat of defamation.

2. In the cases described below $2^{\circ}$, the crime will not be prosecuted except for complaints from the person who committed the crime.

When the compared between the provisions in Article 335 paragraph (1) of the Criminal Code originating from Article 284 of the Dutch WVS, it can be seen that in the original regulation in WVS itself there is no phrase or element of offense as an alternative to offense about unpleasant acts or threat of unpleasant acts. Therefore in article 284 Nederland Wetbook van Straafrecht, it do not include the phrase and only in the Netherlands Wetbook van Straafrecht for Hindi in Indonesia. As we look for the Raison D'eter from the existence of a phrase or element from the offense as an alternative to offense concerning unpleasant act or threat in a form of unpleasant act, historically, that at that time Article 335 paragraph (1) of the Criminal Code is one of the articles that often used by the Dutch who at that time colonized Indonesia therefore could easily imprison the Indonesian citizen. This can be seen from the phrases or elements of offense as an alternative to offense on unpleasant acts or by the threat through unpleasant acts, which thereby used bu the Dutch when there are Indonesian citizens who make the Dutch colonizer uncomfortable, where they apply it to imprison Indonesian citizens at the time. So it is clear, this unpleasant phrase or element of action was one form of Dutch colonialism at the time.

With the removal of the phrase or element of offense as an alternative to offense about unpleasant acts or with the threat of unpleasant acts, therefore an indirect restructuring has occurred by the Constitutional Court. Thus, the true offense of "unpleasant acts" has vanished. However, it does not mean that Article 335 paragraph (1) of the Criminal Code does not exist anymore or is not applicable, in fact there has been a change where, in the past Article 335 paragraph (1) of the Criminal Code is referred to as "unpleasant acts" offense, so now, after the Constitutional Court Decision Number 1 / PUU-X / 2013 changed to "Forced" offense. 
To clarify the author's explanation, a table of changes to Article 335 paragraph (1) of the Criminal Code will be presented before and after the Constitutional Court Decision Number 1 / PUU-X / 2013.

Table 1. Comparison of Article 335 paragraph (1) of the Criminal Code before and after the Decision of the Constitutional Court Number 1 / PUU-X / 2013

\begin{tabular}{lll}
\hline No Difference & $\begin{array}{l}\text { Article 335 paragraph (1) of the } \\
\text { Criminal Code Before the Decision } \\
\text { of the Constitutional Court Number } \\
1 / \text { PUU-X / 2013 }\end{array}$ & $\begin{array}{l}\text { Article 335 paragraph (1) of the } \\
\text { Criminal Code After the } \\
\text { Constitutional Court Decision } \\
\text { Number 1 / PUU-X / 2013 }\end{array}$ \\
\hline $\begin{array}{l}\text { Onfonse who unlawfully forces } \\
\text { others to do, not do or allow } \\
\text { something, by using violence, some } \\
\text { other deeds or unpleasant } \\
\text { treatment/act, or by using the } \\
\text { threat of violence, some form or } \\
\text { unpleasant treatment/act, both }\end{array}$ & $\begin{array}{l}\text { Anyone who unlawfully forces } \\
\text { others to do, not do or allow } \\
\text { something, by using violence, or } \\
\text { by using the threat of violence, } \\
\text { both against themselves and others }\end{array}$ \\
towards the person himself or other \\
people
\end{tabular}

\section{Conclusion}

The Constitutional Court as the guardian of the constitution and the guardian of the human rights whose duty is to ensure that the Law does not contradict the constitution and to not violate human rights, through Decision Number 1 / PUU-X / 2013 has carried out a reconstruction of Article 335 paragraph (1) of the Criminal Code. Through its Decision, the Constitutional Court has stated that the phrase or element of offense as an alternative to offense concerning an unpleasant act or threat in the form of unpleasant act is unconstitutional.

As reviewed in the original offense, in article 284 Nederland Wetbook van Straafrecht which is the source of Article 335 paragraph (1) of the Criminal Code, it can be seen that there is no phrase or element of offense as an alternative offense about unpleasant acts or with threat of unpleasant actions. Thus, after the Constitutional Court Decision Number 1 / PUU-X / 2013 there has been a reconstruction of offense, where if 
in the previous provisions in Article 335 paragraph (1) of the Criminal Code are referred to as "unpleasant acts" offense, now, it turns into an offense of "Forcing "

\section{References}

Arief, B. N. (2000). Kebijakan Legislatif dalam Penanggulangan Kejahatan dengan Pidana Penjara (Cetakan Ke). Semarang: Badan Penerbit.

Arinanto, S., \& Triyanti, N. (2009). Memahami Hukum dari Konstruksi Sampai Implementasi. Jakarta: RajaGrafindo Persada.

Barus, Z. (2017). Analisis Filosofis Tentang Peta Konseptual Penelitian Hukum Normatif Dan Penelitian Hukum Sosiologis. Dinamika Hukum, 13(2), 313.

Budiyanto, C., Prananto, Tan, F, T. (2019). Designing Embedded Case Study Research Approach in Educational Research. International Journal of Pedagogy and Teacher Education, 3(1), 1-18.

Faisal. (2010). Menerobos Positivisme Hukum. Yogyakarta: Rangkang Education.

Hiariej, E. O. S. (2015). Prinsip- Prinsip Hukum Pidana Edisi Revisi. Yogyakarta: Cahaya Atma Pustaka.

Ibrahim, J. E. dan J. (2017). Metode Penelitian Hukum (Normatif dan Empiris). Jakarta: Pranada Media.

M.Hadjon, P., \& Djamiati, T. S. (2008). Arugmentasi Hukum. Yogyakarta: Gadjah Mada University Press.

Mertokusumo, S. (2009). Penemuan Hukum Sebuah Pengantar. Jakarta: Liberty.

Muhdlor, A. Z. (2012). Perkembangan Metodologi Penelitian Hukum. Jurnal Hukum Dan Peradilan, 1(2), 190-206.

Nugraha, X., Izzaty, R., \& Putri, A. A. (2019). Rekonstruksi Batas Usia Minimal Perkawinan Sebagai Bentuk Perlindungan Hukum. 3(1), 40-54.

Prianter Jaya Hairi. (2016). Kontradiksi Pengaturan "Hukum Yang Hidup Di Masyarakat" Sebagai Bagian Dari Asas Legalitas Hukum Pidana Indonesia. Negara Hukum, 7(1), 89-110.

Rares, S. (2012). An International Convention on Off-Shore Hydrocarbon Leaks? Australian and New Zealand Maritime Law Journal, 26(10), 12-25.

Soeroso. (2011). Pengantar Ilmu Hukum. Jakarta: Sinar Grafika.

Soesilo, R. (1994). Kitab Undang-Undang Hukum Pidana (KUHP) Serta KomentarKomentarnya Lengkap Pasal Demi Pasal. Bogor: Politeia.

Sudirman. (2016). Memurnikan Kewenangan Mahkamah Konstitusi Sebagai Lembaga Pengawal Konstitusi (The Guardian of the Constitution). Jurnal Ilmiah Pendidikan Pancasila Dan Kewarganegaraan, 1(1), 49-55. https://doi.org/10.1017/cbo9781316136256

Wirjono Prodjodikoro. (2003). Asas-Asas Hukum Pidana di Indonesia. Bandung: Refika Aditama. 